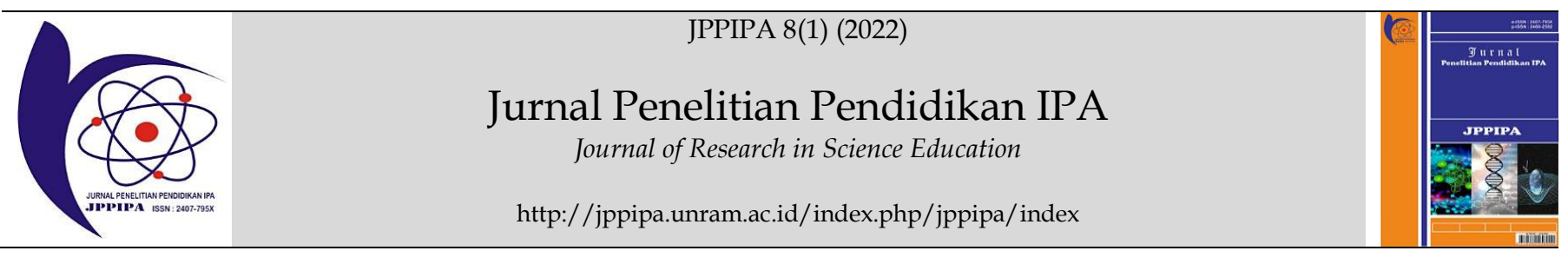

\title{
Feasibility test of STEM at Home Prototype Kit as Science Project- Based Learning Media for Junior High School students
}

\author{
Zulirfan $^{1^{*}}$, Yennita ${ }^{2}$ \\ 1,2 Departement of Mathematics and Science Education, University of Riau, Pekanbaru, Indonesia \\ DOI: $\underline{10.29303 / \text { jppipa.v8i1.1122 }}$
}

\section{Article Info}

Received: November 10, 2021

Revised: January 1, 2022

Accepted: January 5, 2022

Published: January31, 2022

\begin{abstract}
To promote the application of the STEM approach in science learning, it is necessary to provide cheap, easy-to-obtain, and effective STEM project support materials. In addition, science teachers should try to plan and implement STEM in their teaching, even for simple projects. To overcome the problem of the length of time on projects in science teaching, we propose "STEM at Home", a term that means that STEM projects are carried out by students at home under the supervision of parents or families. In order for this home project-based learning to be effective, we have prepared a STEM at Home Kit and Worksheet for Junior High Schools students. We chose the topic Simple. The STEM at Home Kit and Worksheet that have been developed, have received expert approval as learning media that are suitable for use. One-to-one evaluation with 3 participants, and a small group evaluation with 14 participants, were carried out to obtain feedback on students' difficulties in using the product, their perceptions of the product, and their perceptions of the potential impact produced by the instructional product. The results of this evaluation showed that the STEM at Home Project Kit and Worksheet are valid and practically used in science learning, especially on the topic of Simple Machine.
\end{abstract}

Keywords: STEM at home; STEM Project Kit; STEM Worksheet; validation of learning media; the practicality of learning media; feasibility test

Citation: Zulirfan, Z., \& Yennita, Y. (2022). Feasibility test of STEM at Home Prototype Kit as Science Project-Based Learning Media for Junior High School students. Jurnal Penelitian Pendidikan IPA, 8(1), 57-66. https://doi.org/10.29303/jppipa.v8i1.1122

\section{Introduction}

In 21st-century science learning, critical and creative thinking skills are an important concern (Ritter, 2020). The ability to think critically and creatively is very much needed by the younger generation in competing in the job market in the 21st century (Nugroho, et al., 2019; Zulirfan, et al., 2021). Creative thinking can be defined as a whole series of cognitive activities used by individuals according to certain objects, problems, and conditions, or types of efforts towards certain events and problems based on certain capacities (Birgili, 2015). The characteristics of creative thinking are individuals try to use their imagination, intelligence, insight, and ideas when they face a problem. In addition, they try to suggest original and new designs, can generate different hypotheses, can solve problems with the help of finding new applications (Glass, 2004; Young \& Balli, 2014), where each individual realizes his lack of knowledge and tries to bridge this gap. Critical thinking is analyzing and evaluating thinking with the aim of improving it, in other words, independent thinking, discipline, selfmonitoring, and self-correction (Mutakinati, 2018). Critical thinking refers to the ability to analyze information, to determine the relevance of the information collected, and then interpret it in solving problems (Jeevanantham, 2005).

One approach that is considered capable of building critical and creative thinking skills is the STEM approach. This STEM (science-technologyengineering-math) approach combines science, technology, engineering, and mathematics (Gonzalez \& Kuenzi, 2012). Learning science that integrates these five disciplines is important because this integration produces a product that, although simple, can improve 
students' applicative, critical thinking, and creative thinking skills and provide evidence for students that science learning provides benefits for them.

STEM in education is a multidisciplinary learning approach that is expected to build 21st-century skills among students. Many studies show that STEM education has a significant influence in improving critical thinking, creativity, and scientific literacy skills. STEM education can improve higher-order thinking skills in the problem-solving process and in solving problems of everyday life (Jimenez \& Erduran, 2007).

STEM education refers to problem-solving that refers to concepts and procedures from mathematics and science and incorporates engineering design and the use of appropriate technology (Shaughnessy, 2013). The STEM approach is increasingly emphasized because it reflects the interdisciplinary solutions needed to overcome today's complex economic, social, and problems (Bryan et al., 2016; English, 2016; Honey et al., 2014; Sanders, 2009). STEM is a multidisciplinary approach that integrates Science, Engineering, Technology, and Mathematics which are generally embedded in science learning.

The integration of disciplines in STEM is realized in the form of a STEM project. STEM projects in science learning are a concrete form of the application of science concepts. With STEM, students can see that science cannot stand alone and science requires disciplines in producing technological products and even in marketing products. STEM education is defined as an approach to develop knowledge, skills, and beliefs about STEM subjects with an interdisciplinary approach (Corlu, et al., 2014).

There are many problems that cause the STEM approach has not been optimally carried out. These problems include: the assumption that STEM is relatively expensive, projects are difficult to do, spend a lot of time in class hours, and some science teachers are still unfamiliar with the STEM approach. Although, most science teachers admit that they have not implemented STEM in their science teaching, studies show that science teachers have a positive perception of the application of STEM in learning (Bozkurt \& Ercan, 2016).

Taking into account the assumption that learning with the STEM approach always requires relatively expensive costs, especially in the provision of equipment and materials, we take advantage of cheap, simple, and available materials on the market or available in the student environment as a medium for students' STEM learning. To streamline learning time, STEM projects are brought home to be done at home. With STEM at Home, obstacles to indirect learning in the classroom or in the laboratory due to disease outbreaks, smog disasters from forest and land fires, and other factors can be minimized. For that, students need a student worksheet as a guide for working on their STEM projects. Therefore, the ultimate goal of this research is to produce kits and worksheets that are effectively used as learning media based on students' STEM projects with project work that can be done at each student's home. In previous studies, we have found that applying experimental strategies at home can streamline learning (Zulirfan et al., 2018).

As a learning medium, the Home STEM Project Kit and Worksheet that have been designed must meet the criteria for use. STEM project criteria according to Ismail et al., (2016) are as follows: quality design, visual appeal, interactive, coherence with the curriculum, and incorporating STEM elements. Meanwhile, Sudjana \& Rivai (2019) stated that learning media must meet the following criteria: visible, interesting, simple, useful, accurate, legitimate, and structure. Visibility means that learning media must have legibility for students and learning media must be able to attract students' attention (interesting) so that students are encouraged to find out the message that the learning media wants to convey. Meanwhile, learning media must display simplicity so that it is efficient and practical. Learning media must provide benefits in achieving learning objectives. Accurate means that the learning media must be completely in accordance with the learning material. Legitimate, meaning that the learning media is legitimately used to achieve learning objectives. Structured, meaning that learning media cannot be separated from learning materials.

The activity of validating and conducting product testing is an important stage in educational design research (Rusdi, 2019). According to him, the substance of this activity is the same as the formative evaluation of the developed instructional product. According to Rusdi, (2019), the stages of evaluating educational products start with expert assessments, then proceed with one-by-one evaluation, then, continue with small group evaluation. One-to-one evaluation and small group evaluation are needed to obtain information on the practicality of using the product and predict the potential impact of the product. The information obtained from the due diligence process is needed for product improvement.

Validation is an assessment of the feasibility of designing learning media by a team of experts. The expert criteria here are people who are competent in the field of education (Khasanah, et al., 2019). After validation, then proceed to the next stage, namely the reliability stage. Reliability tests are carried out to find out that the measurement results remain consistent if the measurement is carried out twice or more on the same symptoms with the same measuring instrument (Sugiyono, 2010). Reliability is defined as the extent to 
which the test score is free from measurement error (D. Muijs, 2011).

In this research, the feasibility test aims to identify the extent of the difficulties faced by students in using the Kit and student worksheet of STEM at Home that has been designed. Thus, the research question that will be answered in our research relates to the process of testing the feasibility of the Home STEM Kit as a project-based science learning medium for junior high school students. The research questions include: what is the feasibility of the Home STEM Kit and student worksheet as project-based science learning media for junior high school students, to what extent is it easy to use the Home STEM Kit by Junior High School students, and what are the students' perceptions of the use of the Home STEM Kit?

\section{Method}

The feasibility test of the Home STEM Kit and student worksheet as a product of instructional design, in this study, includes expert review, one-to-one evaluation, and small group evaluation. The sequence of the due diligence or validation process is shown in Figure 1.

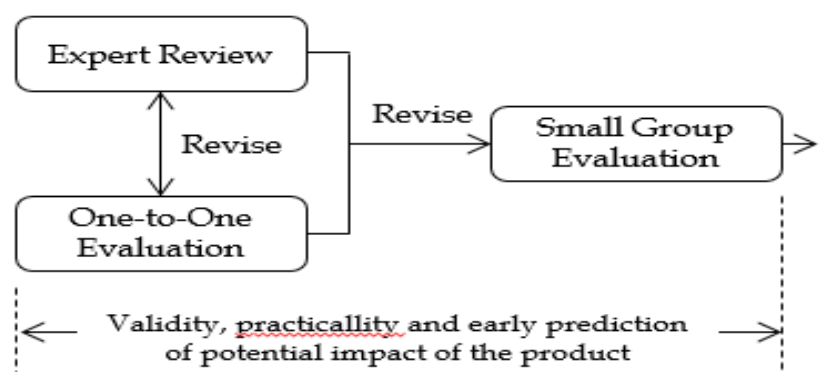

Figure 1. The process of testing the feasibility of the Home STEM Kit and student worksheet (adapted from Rusdi, 2019)

Expert assessment is carried out after the Home STEM Kit and student worksheet have been designed and assembly trials are carried out in the educational laboratory. Assessments were conducted by two science education experts and a senior science teacher. As a learning medium, the Home STEM Kit must meet certain criteria, namely: quality design, visual appeal, interactive, coherence with the curriculum, and incorporating STEM elements (Ismail, et al., 2016).

The expert validation instrument for the Home STEM Kit prototype in this study was developed by adapting aspects of the STEM project according to experts (Ismail et al., 2016; Sudjana \& Rivai, 2019). The expert validation instrument consists of 26 assessment items distributed in 8 assessment aspects, namely: relevance to the curriculum, interactive, flexibility, visual appeal, simplicity, safety, and convenience. Experts are asked to give a score $(0-4)$ to the item being assessed. If an assessment item scores less than 3, the expert will provide an explanation and suggestions for improvement. In this situation, the product draft should be revised. For assessment items that get a score of 3 or 4 , even though it's valid, but experts can provide suggestions for improvement so that the product is more perfect. In this situation, the product can be revised or not at all (Sugiyono, 2017). According to Khasanah (2019), if experts provide a sufficient minimum value, then the product draft is suitable for use in learning.

Meanwhile, the practicality test of the product draft was carried out after the expert assessed the feasibility of the product draft. This practicality assessment is done through one-to-one and small group evaluation. This evaluation is to get feedback on the use of the product draft. In a one-to-one evaluation, 3 students of class VIII SMP have participated in this study. The three participants were given the opportunity to try to assemble a STEM project using the Kit and student worksheet independently. Participants' difficulties and perceptions in using the Kit and student worksheet were identified through direct interviews. The interview protocol instrument used for this purpose consists of 6 aspects, namely: the type of difficulty in the kit and student worksheet, attractiveness, relevance, usefulness, creativity and criticality, and other relevant factors.

Meanwhile, small group evaluations were carried out on 14 students as participants. This step is carried out after the one-by-one assessment stage following revision of the product draft if necessary. Participants were asked to work on a STEM project at home using the STEM Project Kit and guided by the student worksheet. Feedback from participants was collected using a questionnaire containing the following aspects: difficulty in project work, project duration, special treatment in project work, and perceptions of critical and creative thinking skills as the initial potential impact of research products.

The research data were analyzed qualitatively and quantitatively. Qualitatively, the data analysis was grouped based on the tendency of the problems found in the one-to-one test as well as the participants' perceptions of the Home STEM Project Kit and student worksheet. Furthermore, quantitative analysis including mean score and frequency is used to get an initial picture of the practicality and potential impact of the research product.

\section{Result and Discussion}

\section{Expert Review}

A total of 2 science education experts with doctoral qualifications and more than 15 years of 
experience in science education have been asked to provide their assessments as experts on the draft Kit and student worksheet of STEM at Home. Meanwhile, the assessment was also carried out by senior science teachers with more than 10 years of experience teaching science. The results of the expert assessment of the Home STEM Project Kit on the Simple Machines Topic are shown in Table 1.

Table 1. Expert assessment of the STEM at Home Project Kit on Simple Machines topic

\begin{tabular}{lllll}
\hline \multirow{2}{*}{ Aspect } & \multicolumn{4}{c}{ Mean } \\
\cline { 2 - 5 } & P1 & P2 & P3 & Average \\
\hline Coherence with curriculum & 3.60 & 3.40 & 3.40 & 3.47 \\
Interactive & 3.25 & 3.50 & 3.50 & 3.42 \\
Flexibility & $3, .50$ & 3.50 & 3.50 & 3.50 \\
Visual appeal & 3.75 & 3.75 & 3.50 & 3.67 \\
Simplicity & 3.67 & 3.67 & 3.67 & 3.67 \\
Security & 3.67 & 3.67 & 3.67 & 3.67 \\
Convenience & 3.33 & 3.67 & 3.33 & 3.44 \\
Mean & 3.53 & 3.59 & 3.51 & 3.55 \\
\hline
\end{tabular}

Table 1. shows that the Home STEM Project Kit on the Simple Machines topic has met the eligibility criteria as a learning medium for all aspects of the assessment. All experts agree that the Kit is in accordance with the competencies and subject matter of Junior High School Simple Machines. The kit is considered interactive, meaning that the project can be done together or independently, and the project can stop first and then continue again. Kits are also considered flexible in their use, meaning that they can be used for a variety of student STEM projects, and in a way that suits students' creativity, they can be carried anywhere. The expert also considered that the kit fulfills the simplicity aspect, meaning that the kit tools and materials are simple items that are familiar to students, inexpensive, and easy to obtain. In addition, the kit is considered safe to use, does not contain toxic or flammable materials, sharp objects, or easily broken objects. The expert also considered that the kit was easy to use by $8^{\text {th }}$ grade Junior High School students or aged around 14-16 years. The Prototype of STEM at Home Project Kit for Simple Machines topic can be shown in Figure 2.

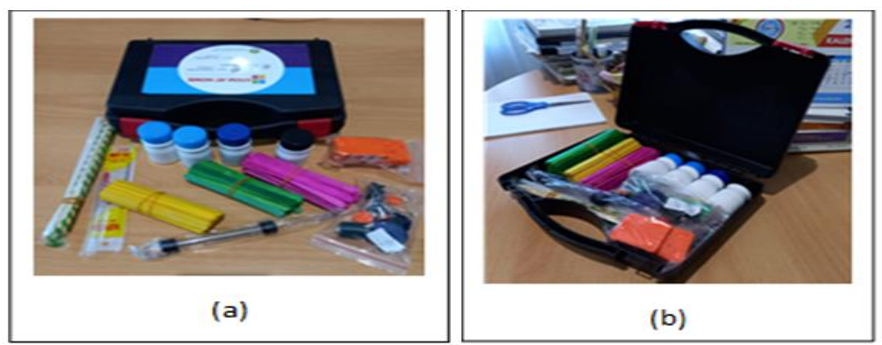

Figure 2. Home STEM Project Kit for Simple Machine, (a) Storage box and tools and materials, (b) Arrangement of tools and materials inbox
Figure 2. shows the prototype of the Simple Machines Home STEM Project Kit. It appears that the kit is relatively small in size, uses cheap and simple items, fulfills the safety aspect, and provides attractiveness. Students take the kit home and work on the kit independently under parental supervision. The results of the expert assessment recommend that the kit does not require any revision.

Meanwhile, the expert assessment of the Home STEM Project Worksheet on the Simple Machines Topic was carried out on 6 aspects of the assessment, namely: relevance to the curriculum, interactive, flexibility, visual appeal, simplicity, and convenience. The results of the student worksheet assessment are shown in Table 2.

Table2. Expert assessment of the STEM at Home student worksheet of Simple Machines Topic

\begin{tabular}{lllll}
\hline \multirow{2}{*}{ Aspect } & \multicolumn{4}{c}{ Average Score of Each Aspect } \\
\cline { 2 - 5 } & P1 & P2 & P3 & Average \\
\hline Coherence with & 3.40 & 3.60 & 3.60 & 3.53 \\
curriculum & & & & \\
Interactive & 3.25 & 3.25 & 3.00 & 3.17 \\
Flexibility & 3.75 & 3.50 & 3.75 & 3.67 \\
Visual appeal & 3.50 & 3.50 & 3.25 & 3.41 \\
Simplicity & 3.00 & 3.67 & 3.67 & 3.45 \\
Convenience & 3.00 & 3.33 & 3.33 & 3.21 \\
Average & 3.38 & 3.48 & 3.44 & 3.35 \\
\hline
\end{tabular}

There are 4 Home STEM projects facilitated by this student worksheet. The four projects are (1) making a Model of Wheelbarrow, (2) making a Model of Pontoon System Seaport, (3) designing a River Crossing Equipment, and (4) making a Model of Container Lifting Equipment. These four projects correspond to the Simple Machines learning materials, namely: levers, inclined Machines, pulleys, and axle wheels.

The results of the expert assessment of the student worksheet as shown in Table 2 show that the Home STEM Project student worksheet on the Simple Machines topic has met the eligibility criteria as a learning medium for all aspects of the student worksheet assessment.

The Home STEM student worksheet as a student guide in working on STEM projects at home can be shown as shown in Figure 3. 

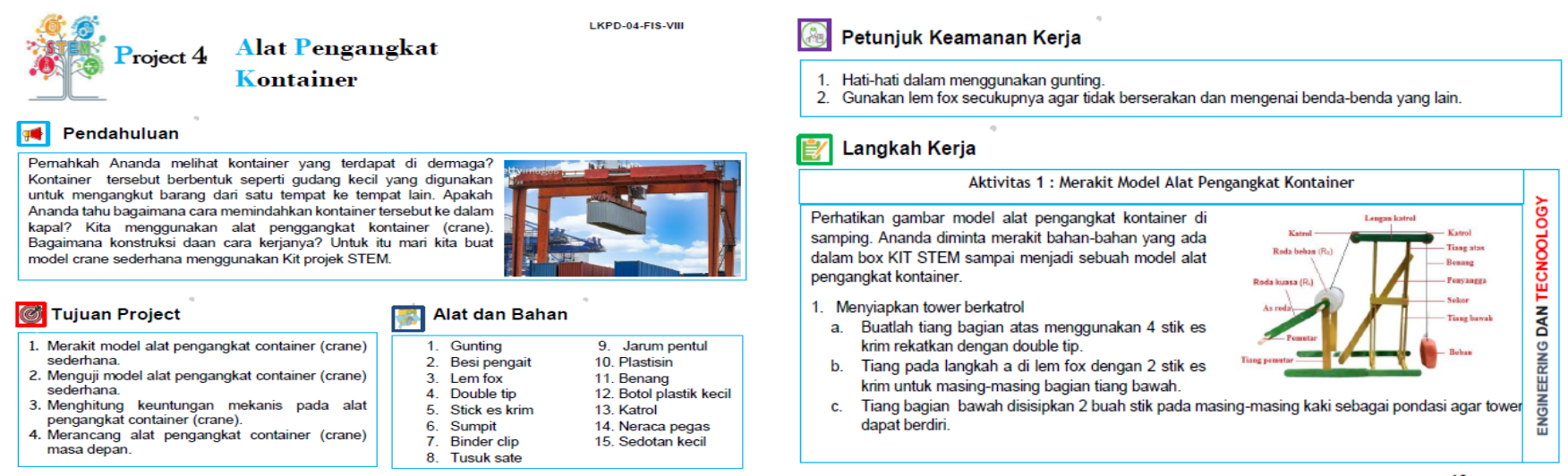

Figure 3. Screenshot of Homework STEM student worksheet as a student guide in working on STEM projects at home

Figure 3. shows a screenshot of the worksheet for one of the projects that students will work on at home. It appears that the activity steps in the student worksheet emphasize aspects of Science, Technology, Engineering, and Mathematics (STEM). Science in this case deals with the concepts of force, work-mechanical energy, and mechanical advantage in simple machines. Technology is related to the use of ICT technology in finding information about simple machines and their applications. Meanwhile, Engineering in this student worksheet is related to design, selection of tools and materials, assembly, to product testing, while Mathematics is concerned with measuring materials and physical quantities, and calculations in applying physics concepts to the resulting product.

This is in accordance with the results of a study by Nugroho et al., (2019) which states that in science teaching, one approach that is considered capable of improving critical and creative thinking skills to face the challenges of the 21st century is the STEM approach. This STEM approach integrates science, technology, engineering, and mathematics (Gonzalez \& Kuenzi, 2012). Studies show that science teachers have a positive perception of the application of STEM in learning (Bozkurt \& Ercan, 2016).

\section{Practical Assessment of Kits and student worksheet}

After getting expert validation of the concepts, constructs, and contents of the Home STEM Project Kit and student worksheet, the researchers also conducted a product practicality assessment. This assessment aims to identify the extent of the difficulties faced by students in using the Kit and student worksheet that have been designed. This assessment is carried out in two stages, namely one-on-one assessment and small group assessment.

\section{One-to-One Evaluation}

The one-to-one evaluation aims to obtain input about the difficulties or confusion experienced by students when creating a Home STEM project using the
Kit and student worksheet developed. The assessment was carried out by means of direct interviews with 3 participants in turn. Aspects of the assessment include difficulty using the kit, difficulty using student worksheet, attractiveness, relevance, benefits, and aspects of creative and critical attitudes. Based on the interview, the findings are as shown in Table 3.

Table 3. Results of one-to-one evaluation of Kit and student worksheet of STEM at Home

\begin{tabular}{lll}
\hline No & Aspect & Student Response \\
\hline 1a & $\begin{array}{l}\text { Difficulty } \\
\text { using the kit }\end{array}$ & $\begin{array}{l}\text { KIT is easy to use to make all three } \\
\text { projects, not difficult to use because the } \\
\text { ingredients are complete. }\end{array}$ \\
1b & $\begin{array}{l}\text { Difficulty } \\
\text { using }\end{array}$ & $\begin{array}{l}\text { The student worksheet is easy to } \\
\text { Worksheet }\end{array}$ \\
& & $\begin{array}{l}\text { use because the sentences are easy } \\
\text { to understand, and the steps are } \\
\text { well explained. }\end{array}$ \\
& & Student worksheet is very \\
helpful in making STEM projects.
\end{tabular}

2 Attractiveness KIT and student worksheets are very interesting and have a positive impact on students because they are new things, and this is the first time for them.

3 Kit relevance It is in line with expectations, because learning STEM Projects is very fun and easy to understand, making students more active and enthusiastic.

$4 \quad$ Benefits

- Increase students' skills to think creatively.

- Increase students' insight and experience in learning Simple Machines.

- Students understand the material better.

5 Creative and New ideas emerge, such as: critical
- Make a well water draw tool

- Make a seesaw

- Make a suspension bridge

- Make the container lifter bigger

- Make a house or tower 
Table 3. shows that the kit was easy to use by the participants, there were no difficulties in working or other problems. The same applies to student worksheets. This is in line with the results of the study by E. Baran et al., (2016) who found that STEM activities carried out by students can be carried out easily and the simulations provided can be run safely, students work with tools and materials that are simple and easy to find. In addition, according to Wijayanti, (2018), it is stated that learning science with a STEM approach has the potential to provide more meaningful learning.

Kit and student worksheet were interesting for them because it was the first time, they had made a project related to learning science. From the aspect of relevance, Kit and STEM student worksheet are in line with students' expectations in learning science. Kits and worksheets also make students more skilled at working on a project and make it easier to understand science material. The important impact is, students recognize they are becoming more critical and creative, such as the emergence of ideas to make other projects that are more challenging. This means that STEM-based learning does not only produce a product in the form of a model or prototype, but science concepts can also be mastered well, because of good mastery of scientific concepts, supported by adequate mathematical abilities, skilled in using information technology, and engineering skills will produce better STEM products.

This is in accordance with the four disciplines that are integrated in the STEM approach, namely science, technology, engineering, and mathematics (Gonzalez \& Kuenzi, 2012).

This is in accordance with the results of the study that higher-order thinking skills such as problemsolving, critical thinking, and creative thinking are the main targets in STEM learning (Barak \& Assal, 2018; Lee et al., 2019). In addition, based on the results of a study by Ariani et al., (2019) showed that students' creative thinking skills increased with good criteria by applying a learning model with a STEM approach.

\section{Small-Group Evaluation}

One-to-one evaluation, recommends that no revision of the Kit and student worksheet is required. Therefore, the validation stage was continued to small group assessment. This assessment was carried out on 14 participants who were grade VIII junior high school students. Participants received an explanation of the Simple Machines material and then they worked on their projects at their respective homes. After that, students were asked to give their opinion about the practicality of the Kit and student worksheet, as well as the potential impact on critical and creative thinking skills. The responses of a small group of participants to a project created using the student worksheet -guided Kit are shown in Table 4.

Table 4. Result of small group evaluation of the use of the STEM at Home Kit guided by student worksheet

\begin{tabular}{|c|c|c|c|}
\hline Project & $\begin{array}{l}\text { Sub } \\
\text { Aspect }\end{array}$ & Opinion & $f(\%)$ \\
\hline \multirow{8}{*}{$\begin{array}{l}\text { Model of } \\
\text { Simple } \\
\text { Wheelbarrow }\end{array}$} & \multirow{4}{*}{$\begin{array}{l}\text { Ease of } \\
\text { working } \\
\text { on projects }\end{array}$} & So easy & 7.14 \\
\hline & & Easy & 78.57 \\
\hline & & Difficult & 14.29 \\
\hline & & Very difficult & 0.00 \\
\hline & \multirow{4}{*}{$\begin{array}{l}\text { Time } \\
\text { required }\end{array}$} & Less than 15 minutes & 0.00 \\
\hline & & 15 - 30 minutes & 14.29 \\
\hline & & 31 - 60 minutes & 35.71 \\
\hline & & Over 60 minutes & 50.00 \\
\hline \multirow{11}{*}{$\begin{array}{l}\text { Model of } \\
\text { Simple } \\
\text { Pontoon } \\
\text { System } \\
\text { Seaport }\end{array}$} & \multirow{4}{*}{$\begin{array}{l}\text { Ease of } \\
\text { working } \\
\text { on projects }\end{array}$} & So easy & 14,29 \\
\hline & & Easy & 78.57 \\
\hline & & Difficult & 7.14 \\
\hline & & Very difficult & 0.00 \\
\hline & \multirow{7}{*}{$\begin{array}{l}\text { Time } \\
\text { required }\end{array}$} & Less than 15 minutes & 7.14 \\
\hline & & 15 - 30 minutes & 14.29 \\
\hline & & $31-60$ minutes & 57.14 \\
\hline & & Over 60 minutes & 21.43 \\
\hline & & So easy & 0.00 \\
\hline & & Easy & 42.86 \\
\hline & & Difficult & 57.14 \\
\hline \multirow{7}{*}{$\begin{array}{l}\text { Model of } \\
\text { Simple } \\
\text { Container } \\
\text { Lifting } \\
\text { Equipment }\end{array}$} & \multirow{4}{*}{$\begin{array}{l}\text { Ease of } \\
\text { working } \\
\text { on projects }\end{array}$} & Very difficult & 7.14 \\
\hline & & & \\
\hline & & & \\
\hline & & Less than 15 minutes & 0.00 \\
\hline & \multirow{3}{*}{$\begin{array}{l}\text { Time } \\
\text { required }\end{array}$} & 15 - 30 minutes & 0.00 \\
\hline & & $31-60$ minutes & 42.86 \\
\hline & & Over 60 minutes & 57.14 \\
\hline
\end{tabular}

All participants admitted that so far, they had never studied science by working on a STEM project like this. Therefore, it is very natural that there are a small number of participants $(14.29 \%)$ who are still having difficulty working on their first home project, namely Making a Model of Wheelbarrow, as shown in Table 4. Participants (50\%) spent more than one hour, while some spent less than one hour.

In project-2: Making a Model of Pontoon System Seaport, the difficulty of the project decreases. Almost all participants claimed that their project tasks were easier to do than before. Only $7.14 \%$ of participants claimed that their projects were difficult to work on. In line with that, the time to work on projects-2 became shorter, namely $14.29 \%$ of participants needed less than half an hour and $57.14 \%$ took between half an hour to one hour. Others take more than an hour.

Meanwhile in project-3: Making Container Lifting Equipment, some participants stated that this project was easy to do and some were vice versa. Accordingly, some participants were able to complete this project in more than an hour and some in less than an hour. This is understandable because the researcher 
designed project-3 with relatively higher complexity for students, compared to the other two projects. In this project-3, there are 2 simple machines that are applied in the project, namely pulleys and axle wheels. Students must ensure that the pulleys and wheels act as planned and the seat must be strong enough to withstand the load and pulling force of the ropes on the axle wheels.

This STEM project designed for Simple Machines learning is actually quite simple for students aged 14-16 years. However, if students have not familiarized themselves with science projects or STEM projects, then their psychomotor skills have not been trained properly. This is in accordance with the results of the study by Ejiwale (2013) which states that one of the problems faced in implementing STEM education is the lack of laboratory facilities and teaching media and students who have not been trained in carrying out project activities. In addition, their creative thinking skills have not been developed properly. This is by the results of a study by Cottrell (2005) which states that students who are accustomed to solving problems to a certain level rely on their thinking, then students' thinking skills will increase, and vice versa. STEM education is something that is still foreign to science teachers in some schools, teachers do not yet know the concept and implementation (Firman, 2015). So that some schools are not familiar with the implementation of STEM.

This causes some students to be too rigid in following the instructions in the student worksheet and their fear of making mistakes in doing the project slows down their project work. However, some students have been able to participate in STEM project-based learning by expectations, namely projects that are easy to do, in about 31-60 minutes. This time interval will be reduced again if students are accustomed to learning with the STEM project approach. If this happens, the students' STEM projects can be further increased in complexity. Teachers who can teach STEM well will be very useful for students in facing a "multidisciplinary" world so that students will be better trained in solving the problems they will face (Wang et al., 2011). In addition, teaching through an integrated approach can increase interest in STEM content, especially if it is taught to students from an early age (Barlex, 2011).

In the small group assessment, things were also identified in the form of special treatment is working on projects using the Home STEM Kit. The special treatment identified is the place and time of working on the project, as well as the parties who assist the participants in working on their project. In addition, the potential impact of using the Home STEM Project Kit and student worksheet was also identified through participants' opinions on material mastery, the emergence of creative ideas, and scientific literacy after working on this home STEM project. The results of small group assessments regarding special treatment in working on projects and potential impacts after working on Home STEM projects are shown in Table 5.

Table 5. Results of small group assessments of special treatment and potential impacts of the Home STEM project

\begin{tabular}{|c|c|c|c|}
\hline Aspect & Sub Aspect & Opinion & $\mathrm{f}(\%)$ \\
\hline \multirow{8}{*}{$\begin{array}{l}\text { Special } \\
\text { treatment }\end{array}$} & \multirow[t]{2}{*}{ A place to work on projects } & Anywhere & 92.86 \\
\hline & & Special place & 14.29 \\
\hline & \multirow[t]{3}{*}{ Time required } & A special time, maybe Saturday or Monday only & 14.29 \\
\hline & & Every day, but enough time to complete the project & 35.71 \\
\hline & & Any time & 50.00 \\
\hline & \multirow[t]{3}{*}{ Anyone who helps } & Independently & 78.57 \\
\hline & & Parents & 21.43 \\
\hline & & Friends & 0.00 \\
\hline \multirow{10}{*}{$\begin{array}{l}\text { Critical and } \\
\text { Creative Ideas }\end{array}$} & \multirow[t]{2}{*}{ Conceptual understanding } & Easy to understand & 85.71 \\
\hline & & Not helpful & 14.29 \\
\hline & \multirow[t]{3}{*}{ Science Literacy } & Can explain and apply & 100.00 \\
\hline & & Can't explain & 0.00 \\
\hline & & Don't know at all & 0.00 \\
\hline & \multirow[t]{2}{*}{ Ideas in another way } & No ideas & 50.00 \\
\hline & & Any other way ideas & 50.00 \\
\hline & \multirow[t]{3}{*}{ Other project ideas } & No ideas & 21.43 \\
\hline & & Any other project ideas & 35.71 \\
\hline & & There are other better ideas & 42.86 \\
\hline
\end{tabular}

On the special treatment aspect of working on Home STEM projects, Table 5. shows that most of the participants can work on their projects anywhere in their home environment. This shows that this Home
STEM Project Kit is quite flexible in its use. Students can work on their projects in the living room, kitchen, bedroom, patio, or in the yard. 
In terms of time, most of the participants did not need the time devoted to working on the project. Some of them work on their home projects at any time, but a minimum of 1 hour must be provided. Meanwhile, most of the participants work on the project at any time. They don't have to complete the project all at once. They can continue the project at any time. A small number need this special time, for example, Sundays are used specifically to work on their home projects. These results lead to the conclusion that the Home STEM project has flexibility in terms of processing time.

In working on home STEM projects, Table 5 shows that most of the participants completed their projects independently. Only a small number are helped by their parents. This is quite encouraging considering that the participants have never worked on a STEM project in their science learning so far. These results indicate that the Home STEM Project Kit meets the aspects of convenience and simplicity.

On the critical and creative aspects, Table 5 shows that most students easily understand the material of simple Machines, can explain the application of simple Machines in everyday life and can explain the working principles of relevant equipment. These results indicate that students are not only ambitious in completing projects, but furthermore, students easily master the material, can apply their understanding in explaining the working principles of technological equipment in daily life in more depth. Meanwhile, the home STEM projects that were carried out were able to generate ideas for some participants to make projects in other ways. The surprising finding was that some participants had ideas to create other projects outside of the assigned tasks, such as making pedestrian bridge models, house models, suspension bridges, and so on, which have also been identified in one-on-one assessments. This is in accordance with the results of a study by Wijayanti, (2018) who found that learning science with a STEM approach has the potential to provide more meaningful learning.

However, further studies are needed to identify whether students really have creative ideas or just a desire to do better. For this reason, further studies will be carried out to determine the real impact of this learning product on learning outcomes or relevant abilities.

\section{Conclusion}

STEM at Home Project Kits and Worksheet has been designed and constructed in order to provide inexpensive, safe, and effective STEM project-based learning media. These products are intended as a medium for working on STEM projects at the home of the students. These STEM kits and worksheets can also be used in school learning. To obtain the validity of this teaching product, a series of feasibility tests have been carried out on this instructional design product, especially for the Simple Machines topic. The feasibility test was conducted to obtain an overview of the extent to which the product has met the theoretical criteria and practicality criteria as a learning medium. The expert's review has shown that the products have met the elements of a learning media and the expert also predicts the potential impact of the product being built. Practical assessment through one-to-one evaluation has shown that the Home STEM Project Kit can be easily used by students in working on relevant projects. The small group evaluation concluded that the Home Project Kit is flexible to use, efficient in terms of time and space, simple, and easy to use. Furthermore, our study will be directed to product testing on a wider scale, namely in real classrooms teaching in schools.

\section{Acknowledgments}

Thanks are conveyed to the Rector of the University of Riau who has provided research funds through the DIPA of the University of Riau in 2021. Thanks, are also conveyed to the Chairperson of the Institute for Research and Community Service at the University of Riau who manages and facilitates this research.

\section{References}

Ariani, L., Sudarmin, \& Nurhayati, S. (2019). Analisis berpikir kreatif pada penerapan problem based learning berpendekatan science, technology, engineering, and mathematics. Jurnal Inovasi Pendidikan Kimia, 13 (1). https://journal.unnes.ac.id/nju/index.php/JIPK /article/view/15159

Barak, M., \& Assal, M. (2018). Robotics and STEM learning: Students' achievements in assignments according to the P3 Task Taxonomy-practice, problem solving, and projects. International Journal of Technology and Design Education, 28 (1), 121-144. https://doi.org/10.1007/S10798-0169385-9

Baran, E., Bilici, S. C., Mesutoglu, C., \& Ocak, C. (2016). Moving STEM beyond schools: Students' perceptions about an out-of-school STEM education program. International Journal of Education in Mathematics Science and Technology, 4 (1), 9-19. https://doi.org/10.18404/ijemst.71338.

Barlex, D. (2011). The Stem Programme in England. In Positioning Technology Education in the Curriculum. Deft, The Netherland: Sense Publishers, 63-74. 
Birgili, B. (2015). Creative and Critical Thinking Skills in Problem-based Learning Environments. Journal of Gifted Education and Creativity, 2 (2), 7180.

https:// doi.org/10.18200/JGEDC.2015214253.

Bozkurt Altan, E., \& Ercan, S. (2016). STEM education program for science teachers: Perceptions and competencies. Journal of Turkish Science Education, 13(Special issue), 103 - 117. https://doi.org/10.12973/tused.10174a.

Bryan, L.A., Moore, T.J., Johnson, C.C., \& Roehrig, G.H. (2016). Integrated STEM education. In C.C. Johnson, E.E. Peters-Burton, \& T.J. Moore (Eds.), STEM Road Map: A Framework for Integrated STEM Education. (pp. 23-37). New York, NY: Routledge.

Corlu, M.S., Capraro, R.M., \& Capraro, M.M. (2014). Introducing STEM education: Implications for educating our teachers in the age of innovation. Education and Science, 39 (171), 74-85. Retrieved from:

http:/ / repository.bilkent.edu.tr/handle/11693/ 13203

Cottrell, S. (2005). Critical Thinking Skills, Developing Effective analysis and Argument. New York: Palgrave Macmillan.

D. Muijs. (2011). Doing Quantitative Research in Education with SPSS. London: SAGE Publications Ltd.

Ejiwale, J.A. (2013). Barriers to Successful Implementation of STEM Education. Journal of Education and Learning, 7 (2), 63-74. https://doi.org/10.11591/edulearn.v7i2.220

English, L. D. (2016). STEM education K-12: Perspectives on integration. International Journal of STEM Education, 3 https:// doi.org/10.1186/s40594-016-0036-1

Firman, H. (2015). Pendidikan Sains Berbasis STEM: Konsep, Pengembangan, dan Peranan Riset Pascasarjana. Prosiding Seminar Nasional Pendidikan IPA dan PKLH. Program Pascasarjana Universitas Pakuan, Bogor.

Glass, T. (2004). What gift? The reality of the student who is gifted and talented in public school classrooms. Gifted Child Today, 2 (4), 25-29. https://doi.org/10.4219/gct-2004-152

Gonzalez, H. B., \& Kuenzi, J. (2012). What is STEM education and why is it important? Congressional Research Service, (August), 1-15.

Honey, M., Pearson, G., \& Schweingruber (Eds.). (2014). STEM integration in K-12 education: Status, prospects, and an agenda for research. Washington D.C: National Academies Press.

Ismail, Permanasari, A., Setiawan, W. (2016). STEM virtual lab: an alternative practical media to enhance student's scientific literacy. Jurnal Pendidikan IPA Indonesia, 5 (2), 239 - 246. https://doi.org/10.15294/jpii.v5i2.5492.

Jeevanantham, L. S. (2005). Why teach critical thinking?. Africa Education Review, 2 (1), 118-129. https://doi.org/10.1080/18146620508566295.

Jimenez-Aleixandre, M. P. \& Erduran, S. (2007). Argumentation in science education: an overview (s. 3-4) [Elektronik Surum]. Dordrecht, The Netherlands: Springer Science + Business Media B.V.

Khasanah, Baiq Uswatul, Aris Doyan, Gunawan, Susilawati, Kartini, Syamsul Hakim, dan Lalu Muliyadi. (2019). Analysis Validation ofLearning Media Quantum Phenomenon. Jurnal Penelitian Pendidikan IPA (JPPIPA), 5 (2), 189-193. https://doi.org/10.29303/jppipa.v5i2.265

Lee, M.-H., Chai, C. S., \& Hong, H.-Y. (2019). STEM education in asia pacific: Challenges and development. Asia-Pacific Education Research, 28 (1), 1-4. https://doi.org/10.1007/s40299-0180424-z.

Mutakinati, L., Anwari, I., \& Yoshisuke, K. (2018). Analysis of students' critical thinking skill of middle school through stem education projectbased learning. Jurnal Pendidikan IPA Indonesia, 7 (1), 54-65. https://doi.org/10.15294/jpii.v7i1.10495.

Nugroho, O. F., Permanasari, A., \& Firman, H. (2019). The movement of stem education in Indonesia: Science teachers' perspectives. Jurnal Pendidikan IPA Indonesia, 8 (3), 417-425. https://doi.org/10.15294/jpii.v8i3.19252.

Ritter, S. M., X. Gu., M. Crijns., and P. Biekens. (2020). Fostering students' creative thinking skills by means of a one-year creativity training program. Research Article PLOS ONE, 15 (3), 1-18. https://doi.org/10.1371/journal.pone.0229773.

Rusdi, M. (2019). Penelitian Desain dan Pengembangan Kependidikan. Depok: Rajawali Pers, PT. Rajawali Grafindo Persada.

Sanders, M. (2009). STEM, STEM education, STEM mania. Technology Teacher, 68, 20-26. Retrieved from

http://esdstem.pbworks.com/f/TTT+STEM+Ar ticle_1.pdf

Shaughnessy, M. (2013). By way of introduction: Mathematics in a STEM context. Mathematics Teaching in the Middle School, 18 (6), 324. https://doi.org/10.5951/mathteacmiddscho.18.6 .0324 .

Sudjana, N dan Rivai, A. (2019). Media Pengajaran. Jakarta: Sinar Baru Algesindo. 
Sugiyono. (2010). Metode Penelitian Pendidikan Pendekatan Kuantitatif, kualitatif, dan RED. Bandung: Alfabeta.

Sugiyono. (2017). Metode Penelitian dan \& Pengembangan (Research and Development). Yogyakarta: Alfabeta Bandung.

Wang, H.H., Moore, T.J., G.H., \& Park, M.S. (2011). STEM Integration: Teacher Perceptions and Practice STEM Integration: Teacher Perceptions and Practice. Journal of Pre-College Engineering Education Research (J-PEER), 1 (2), 1-13. https://doi.org/10.5703/1288284314636.

Wijayanti. A, \& Fajriyah, K. (2018). Implementasi Stem Project Based Learning Untuk Meningkatkan Keterampilan Kerja Ilmiah Mahasiswa Calon Guru SD. Jurnal Pendidikan Sains, 6 (2), 62-69. https://doi.org/10.26714/jps.6.2.2018.62-69.

Young, M.H. \& Balli, S.J. (2014). Gifted and talented education: student and parent perspectives. Gifted Child Today, 37(4), 236-246. https:// doi.org/10.1177/10762175145.

Zulirfan, Iksan Z H, Osman K and Salehudin S N M. (2018). Take-home-experiment: Enhancing students' scientific attitude. Journal of Baltic Science Education, 17 (5), 828 - 837. https://doi.org/10.33225/jbse/18.17.828.

Zulirfan, Z., Rahmad, M., Yennita, Y., dan Purnama, Agus. (2021). Desain dan konstruksi prototype kit proyek STEM sebagai media pembelajaran IPA SMP secara daring pada topik aplikasi listrik dinamis. Journal of Natural Science and Integration, $4 \quad$ (1), $\quad 40 \quad$ - 49. https://doi.org/10.24014/jnsi.v4i1.11446. 